\title{
Glyceraldehyde-3-phosphate dehydrogenase is largely unresponsive to low regulatory levels of hydrogen peroxide in Saccharomyces cerevisiae
}

\author{
Luísa Cyrne ${ }^{1,2}$, Fernando Antunes ${ }^{1,2}$, Ana Sousa-Lopes ${ }^{1}$, João Diaz-Bérrio ${ }^{1}$, H Susana Marinho ${ }^{1,2^{*}}$
}

\begin{abstract}
Background: The reversible oxidation of protein $\mathrm{SH}$ groups has been considered to be the basis of redox regulation by which changes in hydrogen peroxide $\left(\mathrm{H}_{2} \mathrm{O}_{2}\right)$ concentrations may control protein function. Several proteins become S-glutathionylated following exposure to $\mathrm{H}_{2} \mathrm{O}_{2}$ in a variety of cellular systems. In yeast, when using a high initial $\mathrm{H}_{2} \mathrm{O}_{2}$ dose, glyceraldehyde-3-phosphate dehydrogenase (GAPDH) was identified as the major target of S-glutathionylation which leads to reversible inactivation of the enzyme. GAPDH inactivation by $\mathrm{H}_{2} \mathrm{O}_{2}$ functions to reroute carbohydrate flux to produce NADPH. Here we report the effect of low regulatory $\mathrm{H}_{2} \mathrm{O}_{2}$ doses on GAPDH activity and expression in Saccharomyces cerevisiae.

Results: A calibrated and controlled method of $\mathrm{H}_{2} \mathrm{O}_{2}$ delivery - the steady-state titration - in which cells are exposed to constant, low, and known $\mathrm{H}_{2} \mathrm{O}_{2}$ concentrations, was used in this study. This technique, contrary to the common bolus addition, allows determining which $\mathrm{H}_{2} \mathrm{O}_{2}$ concentrations trigger specific biological responses. This work shows that both in exponential- and stationary-phase cells, low regulatory $\mathrm{H}_{2} \mathrm{O}_{2}$ concentrations induce a large upregulation of catalase, a fingerprint of the cellular oxidative stress response, but GAPDH oxidation and the ensuing activity decrease are only observed at death-inducing high $\mathrm{H}_{2} \mathrm{O}_{2}$ doses. GAPDH activity is constant upon incubation with sub-lethal $\mathrm{H}_{2} \mathrm{O}_{2}$ doses, but in stationary-phase cells there is a differential response in the expression of the three GAPDH isoenzymes: Tdh1p is strongly upregulated while Tdh2p/Tdh3p are slightly downregulated.

Conclusions: In yeast GAPDH activity is largely unresponsive to low to moderate $\mathrm{H}_{2} \mathrm{O}_{2}$ doses. This points to a scenario where (a) cellular redoxins efficiently cope with levels of GAPDH oxidation induced by a vast range of sub-lethal $\mathrm{H}_{2} \mathrm{O}_{2}$ concentrations, (b) inactivation of GAPDH cannot be considered a sensitive biomarker of $\mathrm{H}_{2} \mathrm{O}_{2}{ }^{-}$ induced oxidation in vivo. Since GAPDH inactivation only occurs at cell death-inducing high $\mathrm{H}_{2} \mathrm{O}_{2}$ doses, GAPDHdependent rerouting of carbohydrate flux is probably important merely in pathophysiological situations. This work highlights the importance of studying $\mathrm{H}_{2} \mathrm{O}_{2}$-induced oxidative stress using concentrations closer to the physiological for determining the importance of protein oxidation phenomena in the regulation of cellular metabolism.
\end{abstract}

\section{Background}

The preferential and reversible oxidation of specific cysteine residues present in enzymes, transcription factors and receptors has been proposed to be the major mechanism by which oxidants may integrate into cellular signal transduction pathways $[1,2]$. The sulfhydryl

\footnotetext{
* Correspondence: smarinho@fc.ul.pt

'Centro de Química e Bioquímica, Faculdade de Ciências, Universidade de Lisboa, Campo Grande, 1749-016 Lisboa, Portugal

Full list of author information is available at the end of the article
}

(SH) group of cysteine residues, especially when present in an environment that decreases its $\mathrm{pKa}$, can be oxidized by hydrogen peroxide $\left(\mathrm{H}_{2} \mathrm{O}_{2}\right)$, the main cellular reactive oxygen species. The major product of the reaction between a protein cysteinyl thiol and hydrogen peroxide is a protein sulfenic acid $[3,4]$ that, unless in a shielded environment, is a transient intermediate that undergoes a range of secondary reactions $[1,2]$. The protein sulfenic acid can form (a) mixed disulfides with low-molecular weight thiols, mainly glutathione

\section{Biomed Central}


(S-glutathionylation), (b) intramolecular disulfides when vicinal thiols are present, (c) intermolecular disulfides between proteins or (d) reversible condensation with an adjacent amide to form a sulfenylamide. All these oxidations are reversible and, therefore, provide a mechanism by which protein function may be controlled by changes in cellular $\mathrm{H}_{2} \mathrm{O}_{2}$ concentration. When the levels of oxidant exposure are higher further oxidation of cysteinyl sulfenic acids can occur, leading to the formation of cysteinyl sulfinic and sulfonic acids [1,2], which is considered largely irreversible in vivo [5]. Moreover, these higher levels of oxidative stress may often result in excessive disulfide bonding, and in the misfolding, aggregation, and degradation of proteins leading, eventually, to cell death [6,7].

Glyceraldehyde-3-phosphate dehydrogenase (GAPDH) is a classic glycolytic enzyme that is active as a tetramer of identical $37 \mathrm{kDa}$ subunits catalyzing the oxidative phosphorylation of glyceraldehyde-3-phosphate to 1,3diphosphoglycerate by converting $\mathrm{NAD}^{+}$to $\mathrm{NADH}$. More recently, GAPDH emerged as a multifunctional protein with defined functions in numerous subcellular processes, namely a primary role in apoptosis and in a variety of critical nuclear pathways $[8,9]$. In the yeast Saccharomyces cerevisiae (S. cerevisiae) three related but not identical GAPDH enzymes with different specific activities are encoded by unlinked genes designated $T D H 1, T D H 2$ and $T D H 3$ [10]. None of the $T D H$ genes are individually essential for cell viability, but a functional copy of either TDH2 or TDH3 is required since $t d h 2 \Delta t d h 3 \Delta$ cells are not viable [11].

Studies with mammalian cells have identified GAPDH as a target of oxidative modifications resulting in decreased activity following exposure to $\mathrm{H}_{2} \mathrm{O}_{2}[12,13]$. GAPDH has an active-site cysteine residue which, following exposure to $\mathrm{H}_{2} \mathrm{O}_{2}$, can be oxidized to an intramolecular disulfide and cysteic acid [14] and also undergo S-glutathionylation [13]. In S. cerevisiae growing in exponential phase, GAPDH was also identified as a major target of S-glutathionylation $[15,16]$ and also carbonylation [17-19] and a sharp decrease in its enzymatic activity was observed $[15,16,18,20]$ following exposure to $\mathrm{H}_{2} \mathrm{O}_{2}$. In cell extracts exposed to $\mathrm{H}_{2} \mathrm{O}_{2}$ both Thdh $2 \mathrm{p}$ and Thdh $3 \mathrm{p}$ are S-glutathionylated, but in vivo only S-glutathionylation of Thd3p is observed $[15,16,20]$.

Studies of GAPDH inactivation and S-glutathionylation in $S$. cerevisiae cells $[15-18,20]$ have been performed in the exponential phase of growth using bolus additions of high doses of $\mathrm{H}_{2} \mathrm{O}_{2}$ that cause high levels of cell death, and so it is difficult to assess the possible regulatory role of $\mathrm{H}_{2} \mathrm{O}_{2}$ on GAPDH activity by inducing reversible GAPDH thiol oxidation, including S-glutathionylation. Therefore, our main aim with this study was to establish in $S$. cerevisiae cells at what levels, in the range of low to moderate $\mathrm{H}_{2} \mathrm{O}_{2}$ concentrations, is $\mathrm{H}_{2} \mathrm{O}_{2}$ able to cause an inhibition of GAPDH activity due to reversible and irreversible oxidation of the enzyme. To achieve this, instead of the typical $\mathrm{H}_{2} \mathrm{O}_{2}$ bolus addition, we exposed cells to controlled steady-state levels of $\mathrm{H}_{2} \mathrm{O}_{2}$, mimicking the physiological production of $\mathrm{H}_{2} \mathrm{O}_{2}$ in vivo. This methodology allows to study the biological effects of low to moderate levels of $\mathrm{H}_{2} \mathrm{O}_{2}$ [21] and by using it we were able to show that in yeast the overall GAPDH activity only decreases at high doses of $\mathrm{H}_{2} \mathrm{O}_{2}$. We also characterized the differential expression of the three Tdh isoenzymes when cells were exposed to $\mathrm{H}_{2} \mathrm{O}_{2}$ under our controlled conditions of $\mathrm{H}_{2} \mathrm{O}_{2}$ delivery. In stationary-phase cells Tdh1p expression emerged as a target for regulation by low $\mathrm{H}_{2} \mathrm{O}_{2}$ levels.

\section{Results}

What are regulatory $\mathrm{H}_{2} \mathrm{O}_{2}$ concentrations?

A high enough $\mathrm{H}_{2} \mathrm{O}_{2}$ dose will eventually trigger the oxidation of cysteine residues, and so it is important to define whether the doses at which $\mathrm{H}_{2} \mathrm{O}_{2}$ is observed to inhibit GAPDH activity are either in the regulatory low range, or in the toxic high range of $\mathrm{H}_{2} \mathrm{O}_{2}$ concentrations.

To define what a low to moderate steady-state $\mathrm{H}_{2} \mathrm{O}_{2}$ dose is, the activity of catalase, an important antioxidant enzyme that removes $\mathrm{H}_{2} \mathrm{O}_{2}$, was measured. In exponential phase cells, catalase activity was upregulated for a 20 $\mu \mathrm{M}$ steady-state $\mathrm{H}_{2} \mathrm{O}_{2}$ exposure and for $40 \mu \mathrm{M} \mathrm{H}_{2} \mathrm{O}_{2}$ there was a two-fold increase in catalase activity (Figure 1A). As to stationary-phase, cells treated with $\mathrm{H}_{2} \mathrm{O}_{2}$ on the lower range of concentrations studied $(50 \mu \mathrm{M})$ showed an increase in catalase activity (Figure 1B). This increase in catalase activity was modest when compared to that observed in exponential-phase cells, probably because catalase activity in stationary-phase cells is 15fold higher than in exponential-phase cells, reflecting a probable higher formation of $\mathrm{H}_{2} \mathrm{O}_{2}$ due to mitochondrial respiration. However, for our purpose this increase in catalase activity observed at $50 \mu \mathrm{M}$ steady-state $\mathrm{H}_{2} \mathrm{O}_{2}$ was sufficient to identify a range of concentrations where $\mathrm{H}_{2} \mathrm{O}_{2}$ triggers a regulatory response. S. cerevisiae has two catalases, peroxisomal catalase (catalase A) and cytosolic catalase (catalase $\mathrm{T}$ ), encoded by the CTA1 and CTT1 genes respectively, and both are known to be induced by $\mathrm{H}_{2} \mathrm{O}_{2}$ [22]. $\mathrm{H}_{2} \mathrm{O}_{2}$-dependent upregulation of CTT1 expression has been shown to be dependent on the transcription factors Yap1p, Skn7p [23] and Msn2p/ Msn4p [24] and it should be pointed out that the minimum $\mathrm{H}_{2} \mathrm{O}_{2}$ concentration needed to activate those transcription factors, when using a bolus addition, was found to be $100 \mu \mathrm{M}[25,26]$.

To define what a high dose of $\mathrm{H}_{2} \mathrm{O}_{2}$ is, the survival of $S$. cerevisiae wild-type cells exposed to steady-state 

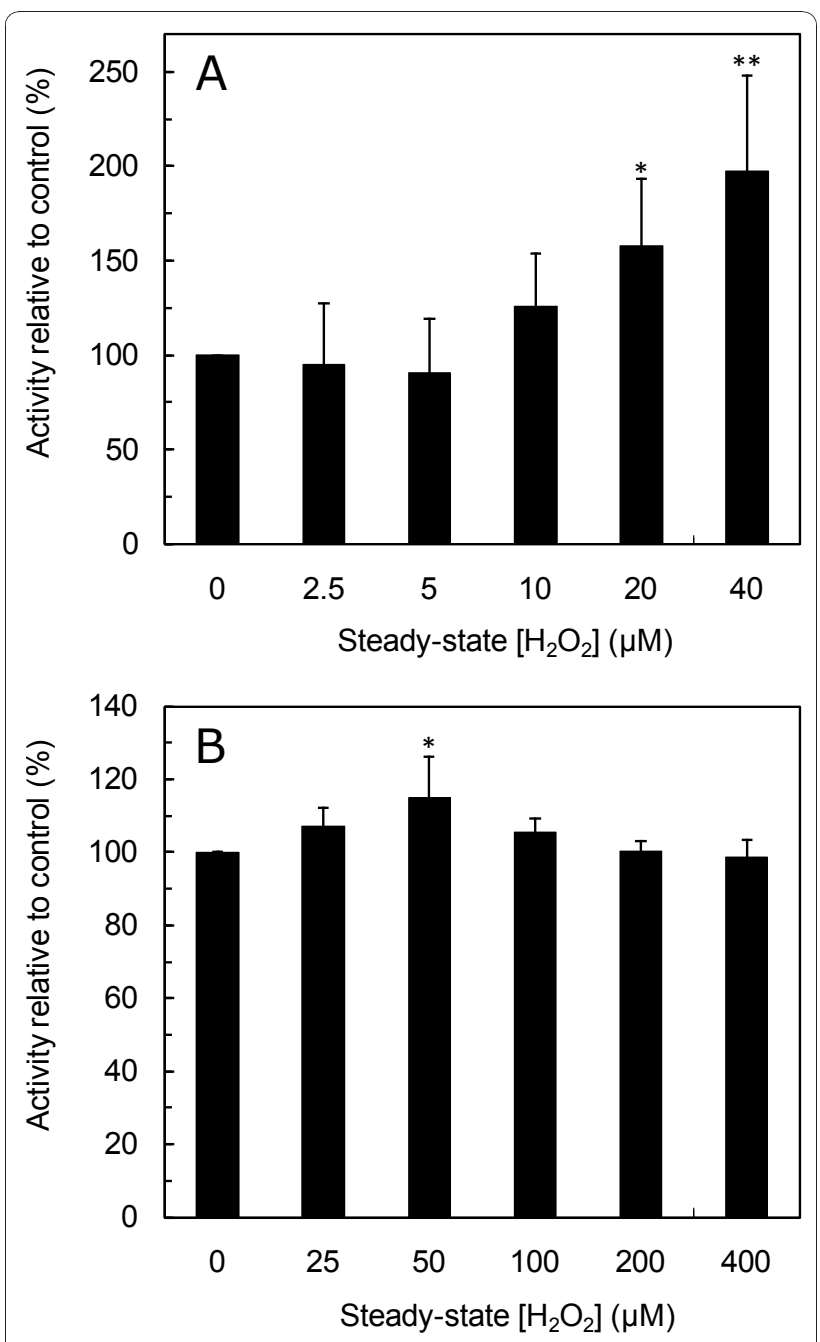

Figure 1 Low concentrations of $\mathrm{H}_{2} \mathrm{O}_{2}$ increase catalase activity in S. cerevisiae. Exponential-phase cells (A) and stationary-phase cells (B) were exposed to the indicated steady-state $\mathrm{H}_{2} \mathrm{O}_{2}$ concentrations for $60 \mathrm{~min}$. The values are the mean \pm standard deviation of $\mathrm{n} \geq 5$ independent experiments. The activity of control cells (without added $\mathrm{H}_{2} \mathrm{O}_{2}$ ) was $0.29 \pm 0.07 \mathrm{~min}^{-1} \mathrm{mg}^{-1}$ for exponential-phase cells and $4.51 \pm 0.67 \mathrm{~min}^{-1} \mathrm{mg}^{-1}$ for stationaryphase cells. ${ }^{*} \mathrm{P}<0.05$ vs control; ${ }^{*} \mathrm{P}<0.001$ vs control.

concentrations of $\mathrm{H}_{2} \mathrm{O}_{2}$ was determined. For exponential-phase cells, under our conditions, the value of 200 $\mu \mathrm{M}$ can be defined as the border between moderate and high toxic conditions because higher steady-state $\mathrm{H}_{2} \mathrm{O}_{2}$ concentrations lead to significant cell death (approximately $55 \%$ for $400 \mu \mathrm{M} \mathrm{H}_{2} \mathrm{O}_{2}$ and $80 \%$ for $700 \mu \mathrm{M} \mathrm{H}_{2} \mathrm{O}_{2}$ ) (Figure 2). For stationary-phase cells, doses up to $800 \mu \mathrm{M}$ may be considered moderate because they did not alter cell survival, which is in agreement with the known higher resistance of these cells to $\mathrm{H}_{2} \mathrm{O}_{2}$ when compared to exponential-phase cells [27].

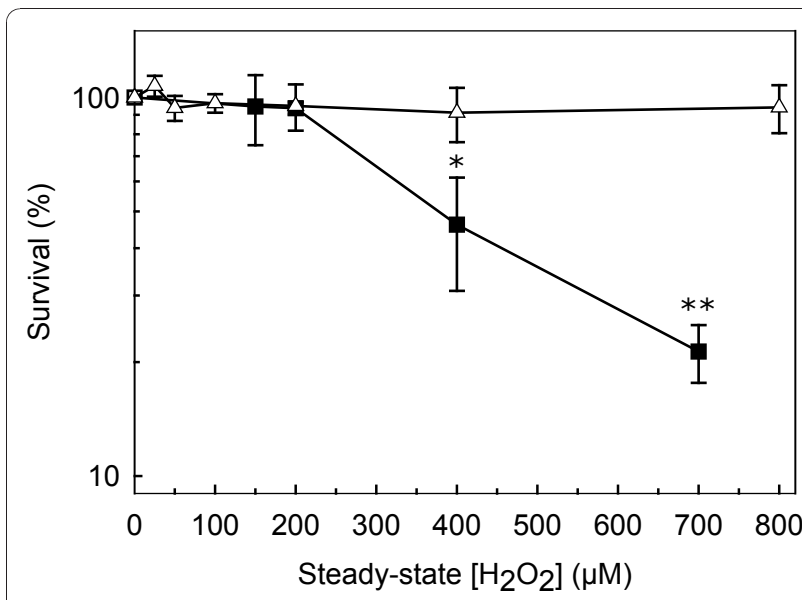

Figure 2 Susceptibility of $S$. cerevisiae cells to steady-state $\mathrm{H}_{2} \mathrm{O}_{2}$-induced oxidative stress. Survival fractions are shown for exponential-phase cells $(-)$ and stationary-phase cells $(\Delta)$ that were exposed to steady-state $\mathrm{H}_{2} \mathrm{O}_{2}$ between $25 \mu \mathrm{M}$ and $800 \mu \mathrm{M}$ for 60 min. The values are the mean \pm standard deviation of $n \geq 3$ independent experiments. ${ }^{*} P<0.05$ vs control; ${ }^{*} P<0.01$ vs control.

In conclusion, steady-state $\mathrm{H}_{2} \mathrm{O}_{2}$ concentrations in the range $20 \mu \mathrm{M}$ to $50 \mu \mathrm{M}$ may be viewed as triggering a regulatory $\mathrm{H}_{2} \mathrm{O}_{2}$ response in $S$. cerevisiae.

\section{Low to moderate concentrations of $\mathrm{H}_{2} \mathrm{O}_{2}$ do not lead to changes in GAPDH activity in S. cerevisiae exponential- phase cells}

GAPDH activity was determined with and without the reducing agent DTT in the assay medium. The difference in the enzyme activity in both assays measures GAPDH reversible inactivation due either to Sglutathionylation, formation of a sulphenic acid or of an intramolecular disulfide. In control cells the activity of GAPDH measured in the absence of DTT was approximately $10 \%$ lower than in the presence of DTT (Figure $3 \mathrm{~A})$, indicating either that the enzyme was partially oxidized in vivo or that it became oxidized during protein extraction. This partial oxidation of GAPDH in unstressed cells has been previously found $[28,29]$. If the reversible inactivation of GAPDH induced by $\mathrm{H}_{2} \mathrm{O}_{2}$, namely by S-glutathionylation, has an important role in the regulation of GAPDH activity during oxidative stress it should be expected that a higher reversible inactivation of the enzyme would occur when cells are exposed to low to average $\mathrm{H}_{2} \mathrm{O}_{2}$ concentrations (i.e., 20-50 $\mu$ M, as defined in the previous point).

When exponential-phase cells were exposed to increasing steady-state $\mathrm{H}_{2} \mathrm{O}_{2}$ concentrations no changes in GAPDH activity determined both in the presence and absence DTT were observed for $\mathrm{H}_{2} \mathrm{O}_{2}$ concentrations up to $160 \mu \mathrm{M}$ (Figure 3A). This dose is 8 times higher 

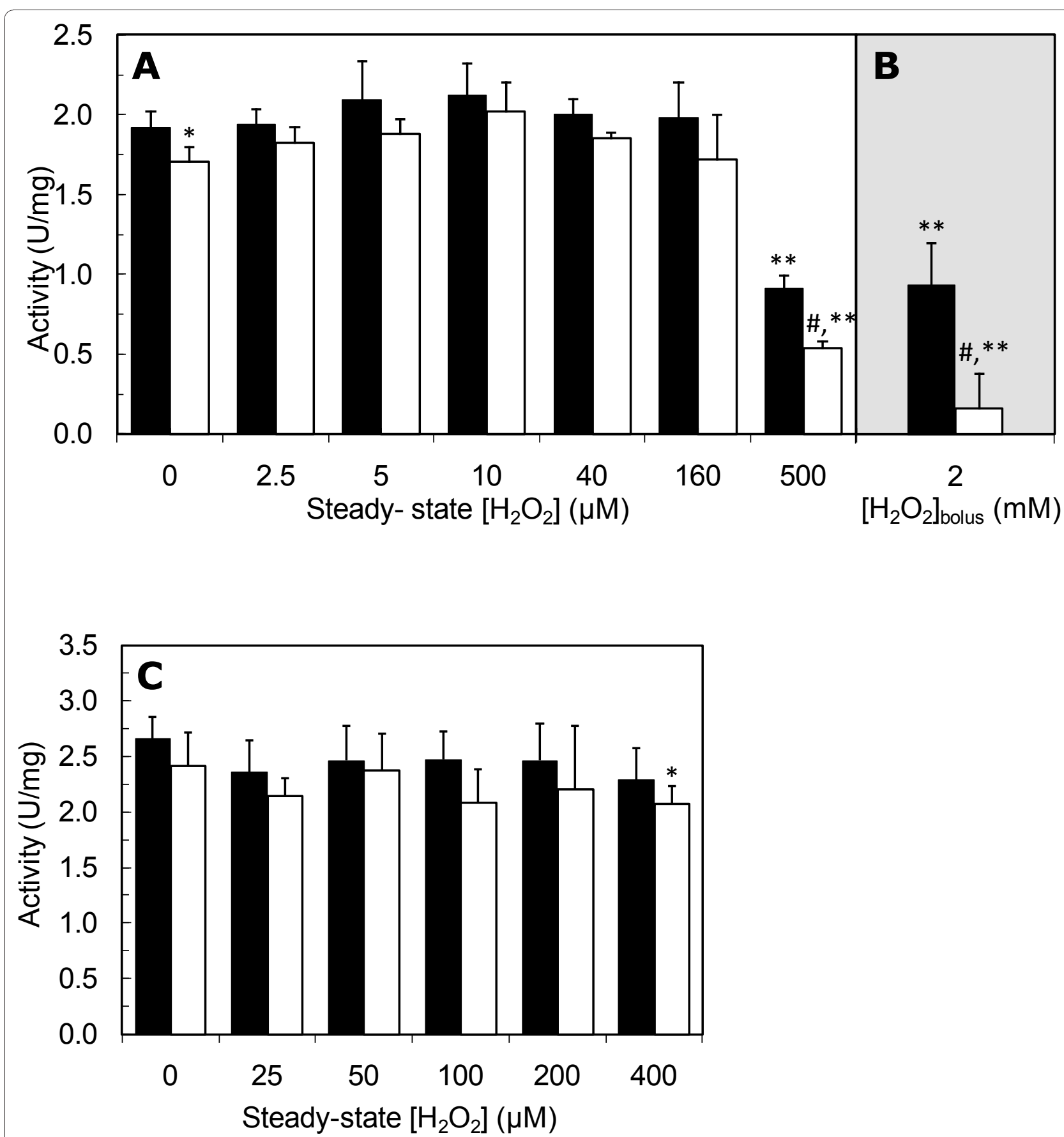

Figure 3 Low $\mathrm{H}_{2} \mathrm{O}_{2}$ concentrations do not inactivate GAPDH in S. cerevisiae. GAPDH activity in exponential-phase cells (A, B) or stationaryphase cells (C) treated with either the indicated steady-state $\mathrm{H}_{2} \mathrm{O}_{2}$ concentrations for 60 min or (B) with a 2 mM $\mathrm{H}_{2} \mathrm{O}_{2}$ bolus addition for 30 min was measured in the presence (closed bars) and in the absence of DTT (dashed bars) in the assay medium. The difference of the activity measured in the presence and in the absence of DTT is a measure of reversible GAPDH thiol oxidation. The values are the mean \pm standard deviation of $3 \leq n<10$ independent experiments. ${ }^{* P}<0.05$ vs DTT; ${ }^{*} \mathrm{P}<0.01$ vs DTT; ${ }^{* * P}<0.001$ vs control.

than the $\mathrm{H}_{2} \mathrm{O}_{2}$ concentration identified as being able to induce catalase activity and is close to the steady-state $150 \mu \mathrm{M} \mathrm{H}_{2} \mathrm{O}_{2}$ dose that induces a multi-factorial cellular response causing adaptation to $\mathrm{H}_{2} \mathrm{O}_{2}$ [30]. Previous studies of GAPDH inactivation by $\mathrm{H}_{2} \mathrm{O}_{2}$ in yeast were done with bolus additions $[15,16,18,20]$, which require the use of a much higher initial $\mathrm{H}_{2} \mathrm{O}_{2}$ concentration. When a typical bolus addition of $2 \mathrm{mM} \mathrm{H}_{2} \mathrm{O}_{2}$ was added to exponential-phase cells (Figure 3B), after 30 min GAPDH activity had decreased to $10 \%$ of that in 
control cells $(1.73 \pm 0.10$ and $0.17 \pm 0.09 \mathrm{U} / \mathrm{mg}$ in control and $\mathrm{H}_{2} \mathrm{O}_{2}$-treated cells respectively). Part of this inactivation induced by the $\mathrm{H}_{2} \mathrm{O}_{2}$ bolus addition was due to reversible GAPDH thiol oxidation since GAPDH activity in $\mathrm{H}_{2} \mathrm{O}_{2}$-treated cells measured in the presence of DTT was about $47 \%$ of that in control cells $(1.99 \pm$ 0.18 and $0.93 \pm 0.20 \mathrm{U} / \mathrm{mg}$ for control cells and $\mathrm{H}_{2} \mathrm{O}_{2}$ treated cells respectively). So, a much higher steadystate concentration of $\mathrm{H}_{2} \mathrm{O}_{2}(500 \mu \mathrm{M})$ was used in order to try to obtain a similar GAPDH inactivation to that observed when using a bolus addition of $\mathrm{H}_{2} \mathrm{O}_{2}$. When exponential-phase cells were exposed to a steady-state $500 \mu \mathrm{M} \mathrm{H}_{2} \mathrm{O}_{2}$ concentration, GAPDH activity showed a marked decrease (to $26 \%$ and $40 \%$ of GAPDH activity in the absence and presence of DTT, respectively) (Figure $3 \mathrm{~A})$. However, it should be noted that similarly to what happens with a $2 \mathrm{mM}$ bolus $\mathrm{H}_{2} \mathrm{O}_{2}$ addition [16], cell survival when cells are subjected to a steady-state 500 $\mu \mathrm{M} \mathrm{H}_{2} \mathrm{O}_{2}$ concentration is lower than $50 \%$ (Figure 2).

In conclusion, for cells in the exponential phase GAPDH activity is largely unresponsive to low to moderate $\mathrm{H}_{2} \mathrm{O}_{2}$ levels, in opposition to a widely accepted view. GAPDH activity does decrease, but only for $\mathrm{H}_{2} \mathrm{O}_{2}$ concentrations that cause significant cell death.

\section{$\mathrm{H}_{2} \mathrm{O}_{2}$ does not inactivate irreversibly GAPDH in $\mathrm{S}$. cerevisiae stationary-phase cells}

GAPDH activity in stationary-phase cells is about 25\% higher than in exponential-phase cells $(2.71 \pm 0.20 \mathrm{U} /$ $\mathrm{mg}$ and $2.03 \pm 0.17 \mathrm{U} / \mathrm{mg}$ respectively, $\mathrm{P}<0.001)$. No changes in GAPDH activity were found for stationaryphase cells treated with steady-state $\mathrm{H}_{2} \mathrm{O}_{2}$ concentrations up to $400 \mu \mathrm{M}$ (Figure 2C) both in the presence and absence of DTT, when compared with control cells. However, for cells exposed to $400 \mu \mathrm{M} \mathrm{H}_{2} \mathrm{O}_{2}$ there was a significant difference in GAPDH activity determined in the presence and absence of DTT, indicating a small increase in the GAPDH reversible oxidation induced by $\mathrm{H}_{2} \mathrm{O}_{2}$. Nevertheless, this $\mathrm{H}_{2} \mathrm{O}_{2}$ concentration is much higher than the $50 \mu \mathrm{M}$, identified in Figure 1 which induces catalase. Therefore, GAPDH may not be considered to be a sensitive target of $\mathrm{H}_{2} \mathrm{O}_{2}$ in stationary phase cells.

\section{Tdh2p/Tdh3p expression is not altered by $\mathrm{H}_{2} \mathrm{O}_{2}$ in} exponential-phase $S$. cerevisiae cells

Up until now we have focused on the activity of GAPDH as a whole. Next we evaluate the pattern of expression of each of the three GAPDH isoenzymes. To this end, 2-dimensional gel electrophoresis followed by immune detection was performed (Figures 4, 5 and 6). Previous studies have shown that in two-dimensional gels Tdh $2 p$ and Tdh3p slightly overlap, while Tdh $1 p$ migrates in a different position $[18,31]$. As can be seen

\section{Tdh2p/Tdh3p Tdh1p}
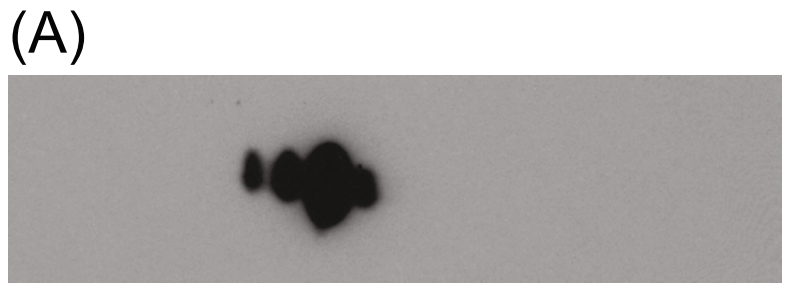

(B)
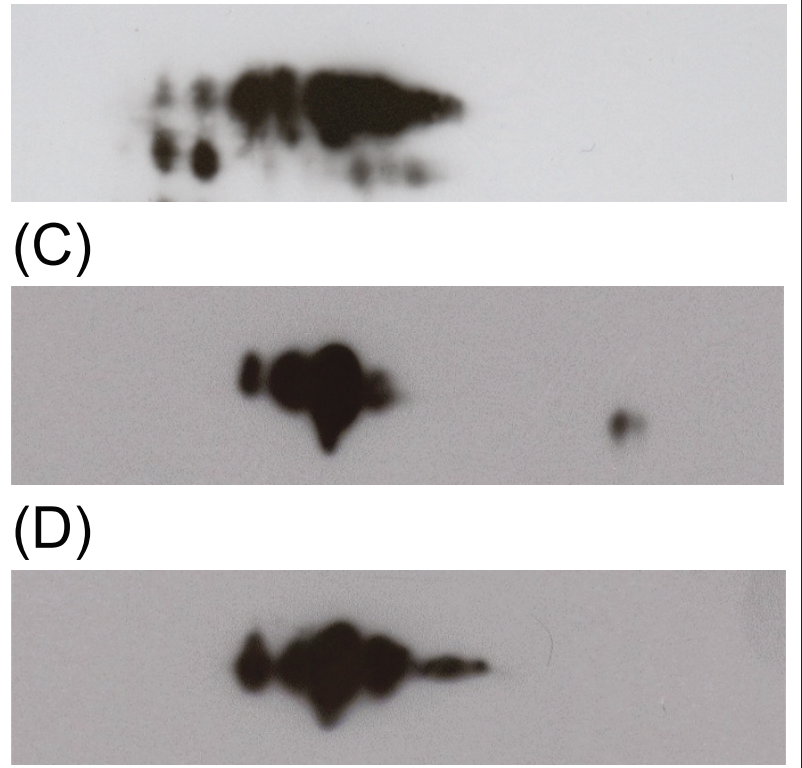

Figure 4 Characterization of the antibodies used for GAPDH detection. Representative $(n \geq 3)$ two-dimensional analysis of Tdh $1 p$, Tdh $2 p$ and Tdh $3 p$ (only the region with the 3 GAPDH isoenzymes is shown) S. cerevisiae cells with immunodetection made by Western blot as described in materials and methods are shown. (A) wt stationary-phase cells with identification using mouse anti-GAPDH (Chemicon MAB374). Identification using rabbit anti-GAPDH was performed in (B) wt exponential-phase cells, (C) wt stationary-phase cells, and (D) tdhis stationary-phase cells.

in Figure 4 the mouse anti-GAPDH (Chemicon MAB374) reacted only with Tdh2p and Tdh3p (Figure $4 \mathrm{~A}$ ), while the rabbit anti-GAPDH reacted with all three isoforms present in stationary-phase cells (Figure 4C). Tdh1p identification was confirmed using a $t d h 1 \Delta$ strain (Figure 4D). Tdh1p was not detected in exponentialphase cells (Figure 4B), which is in agreement with previous studies $[18,32,33]$ where Tdh1p has been described as a minor GAPDH isoenzyme only expressed in the stationary phase of growth. Tdh1p was also not detected when exponential-phase cells were exposed to $20 \mu \mathrm{M}$ and $160 \mu \mathrm{M}$ steady-state $\mathrm{H}_{2} \mathrm{O}_{2}$ (results not shown). Since Tdh2p and Tdh3p levels were difficult to obtain from the 2D-analysis, Western blot analysis from 


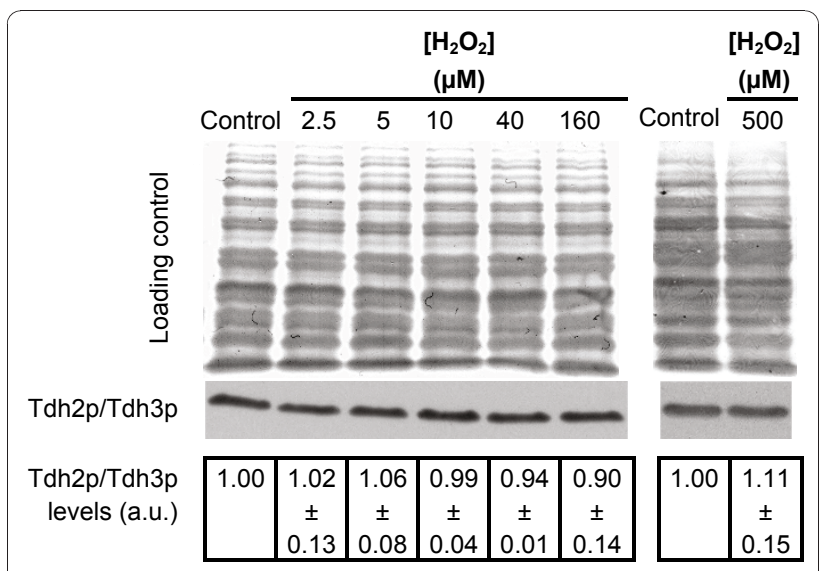

Figure $5 \mathrm{Tdh} 2 \mathrm{p}$ and Tdh $3 p$ protein levels are not affected by $\mathrm{H}_{2} \mathrm{O}_{2}$ in exponential-phase $\mathrm{S}$. cerevisiae cells. Cells were treated with the steady-state $\mathrm{H}_{2} \mathrm{O}_{2}$ concentrations indicated for $60 \mathrm{~min}$. Representative protein loading and immunoblot analysis of Tdh2p/ Tdh3p ( $n=5)$ and signal intensity quantification expressed as the mean \pm standard deviation in arbitrary units (a.u.) relative to control. Mouse anti-GAPDH that only reacts with Tdh2p and Tdh3p was used for Tdh2p/Tdh3p identification.

SDS-PAGE using the mouse anti-GAPDH followed by signal intensity analysis was used to quantify both Tdh2p and Tdh3p levels when cells were exposed to $\mathrm{H}_{2} \mathrm{O}_{2}$. In Figure 5 it can be seen that exposure of exponential-phase cells up to $500 \mu \mathrm{M} \mathrm{H}_{2} \mathrm{O}_{2}$ did not alter the levels of Tdh $2 p / T d h 3 p$ expression. This contradicts observations obtained with higher $\mathrm{H}_{2} \mathrm{O}_{2}$ doses, where a downregulation of Tdh2p/Tdh3p de novo synthesis [34] and Tdh2p/Tdh3p mRNA steady-state levels [35] was observed, and highlights the multitude of possible responses caused by different $\mathrm{H}_{2} \mathrm{O}_{2}$ doses.

\section{$\mathrm{H}_{2} \mathrm{O}_{2}$ upregulates $\mathrm{Tdh} 1 \mathrm{p}$ expression and downregulates $\mathrm{Tdh} 2 \mathrm{p} / \mathrm{Tdh} 3 p$ expression in stationary-phase $\mathrm{S}$. cerevisiae cells}

Unlike what happens in exponential-phase cells where exposure to $\mathrm{H}_{2} \mathrm{O}_{2}$ does not alter GAPDH expression, in stationary-phase cells a slight downregulation of Tdh2p/ Tdh3p expression was observed for higher $\mathrm{H}_{2} \mathrm{O}_{2}$ concentrations (Figure 6A). In fact, after exposure to 160 $\mu \mathrm{M} \mathrm{H}_{2} \mathrm{O}_{2} \mathrm{Tdh} 2 \mathrm{p} / \mathrm{Tdh} 3 \mathrm{p}$ steady-state levels were about $80 \%$ of those in control cells. On the other hand, Tdh $1 \mathrm{p}$ expression in stationary-phase cells was upregulated by $\mathrm{H}_{2} \mathrm{O}_{2}$ since Tdh1p levels were 3.5 fold higher in cells exposed to steady-state $50 \mu \mathrm{M} \mathrm{H}_{2} \mathrm{O}_{2}$ than in control cells (Figure 6B). Therefore, Tdh $1 \mathrm{p}$ emerges as a protein that is strongly induced by low concentrations of $\mathrm{H}_{2} \mathrm{O}_{2}$ in stationary-phase cells.

\section{Discussion}

It has been established for a number of years that oxidation of particular proteins containing reactive cysteine residues, such as GAPDH, occurs when mammalian and yeast cells are exposed to $\mathrm{H}_{2} \mathrm{O}_{2}$. However, in most of these studies, cells are exposed to exogenous $\mathrm{H}_{2} \mathrm{O}_{2}$ concentrations several orders of magnitude higher (millimolar) than the physiological concentration [36], due to its rapid removal by intracellular catalases and peroxidases. Therefore, protein oxidation and enzyme inactivation caused by $\mathrm{H}_{2} \mathrm{O}_{2}$ has been mostly established for situations when cells were under severe oxidative stress and already dying either by apoptosis or necrosis, and thus very far from a regulatory situation. Much less is known [e.g. $[37,38]]$ about the effect of $\mathrm{H}_{2} \mathrm{O}_{2}$ concentration ranges (micromolar) where $\mathrm{H}_{2} \mathrm{O}_{2}$ may affect signaling processes and protein function through reversible changes in protein thiols redox state. In this work, a calibrated method of $\mathrm{H}_{2} \mathrm{O}_{2}$ delivery to cells was used where cells were exposed to steady-state concentrations of $\mathrm{H}_{2} \mathrm{O}_{2}$ throughout the experiment, which allows the use of much smaller concentrations of $\mathrm{H}_{2} \mathrm{O}_{2}$ [21,39]. This made possible to study for the first time in $\mathrm{S}$. cerevisiae cells how low concentrations of $\mathrm{H}_{2} \mathrm{O}_{2}$ affect GAPDH activity and expression. Our study showed that GADPH activity in S. cerevisiae cells, both in the exponential-phase and stationary-phase of growth, is not inhibited by exposure to exogenous low to moderate $\mathrm{H}_{2} \mathrm{O}_{2}$ levels. This was unexpected considering previous studies of GAPDH inactivation by $\mathrm{H}_{2} \mathrm{O}_{2}$ in yeast $[15-18,20]$ and suggests that in yeast cells exposed to low to moderate $\mathrm{H}_{2} \mathrm{O}_{2}$ concentrations the enzymatic systems responsible for the maintenance of cellular protein thiols $[20,40]$, have enough activity to maintain the $\mathrm{SH}$ groups of the reactive cysteine residues in the GAPDH active centre mostly in the reduced form, thus avoiding inactivation of the enzyme. Also, S. cerevisiae exponential-phase cells response to high $\mathrm{H}_{2} \mathrm{O}_{2}$ doses includes the upregulation of the proteins involved in the glutaredoxin and thioredoxin systems [34,41], which are responsible for the reduction of protein disulfides.

Stationary-phase cells have higher resistance to $\mathrm{H}_{2} \mathrm{O}_{2}$ than exponential phase cells which is in part due to the higher catalase activity (Figure 2) and also to a lower cellular permeability to $\mathrm{H}_{2} \mathrm{O}_{2}$ [27]. So, when exposed to the same exogenous $\mathrm{H}_{2} \mathrm{O}_{2}$ concentration stationaryphase cells have a lower intracellular $\mathrm{H}_{2} \mathrm{O}_{2}$ concentration than exponential-phase cells [27]. Also, the levels of glutaredoxins [41] and thioredoxins [42] expression are upregulated in the stationary phase of growth. This probably partially explains why in stationary-phase cells overall GAPDH activity is not inhibited for the whole range of $\mathrm{H}_{2} \mathrm{O}_{2}$ concentrations used in this work. Unlike what happens for exponential-phase cells, where Tdh2p and Tdh3p levels are not altered by exposure to $\mathrm{H}_{2} \mathrm{O}_{2}$ and Tdh1p is not detected, in stationary-phase cells Tdh2p and Tdh3p levels were slightly downregulated at 

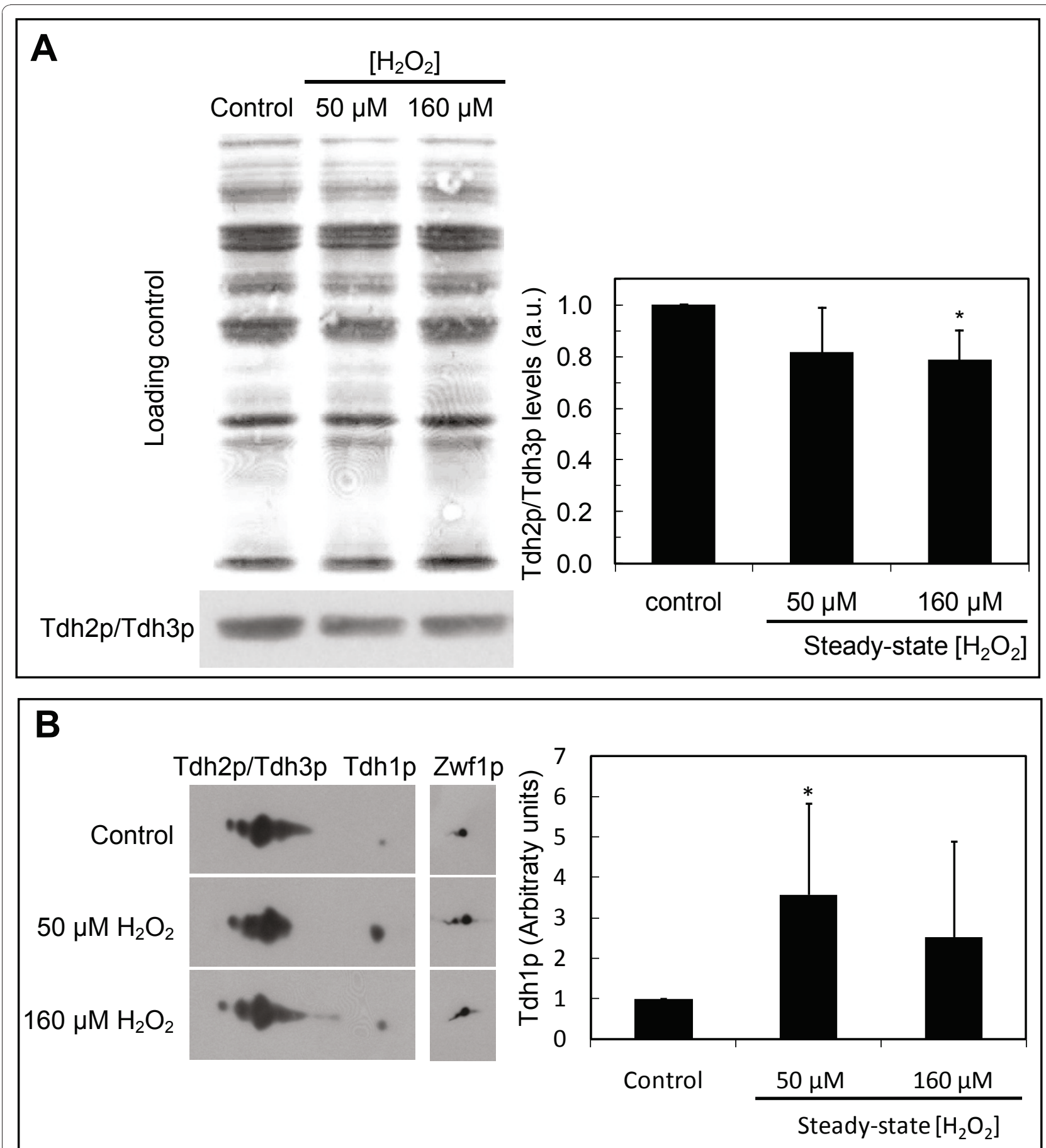

Figure 6 Low concentrations of $\mathrm{H}_{2} \mathrm{O}_{2}$ upregulate Tdh1p and high concentrations downregulate Tdh2p and Tdh3p protein levels in stationary-phase S. cerevisiae cells. Cells were treated with the steady-state $\mathrm{H}_{2} \mathrm{O}_{2}$ concentrations indicated for 60 min. (A) Representative protein loading and immunoblot analysis of $\operatorname{Tdh} 2 \mathrm{p} / \operatorname{Tdh} 3 \mathrm{p}(n=6)$ and signal intensity quantification expressed as the mean \pm standard deviation in arbitrary units (a.u.) relative to control. Mouse anti-GAPDH, which only reacts with Tdh2p and Tdh3p, was used for Tdh2p/Tdh3p identification (see Figure 3). (B) Representative two-dimensional analysis of Tdh1p, Tdh2p and Tdh3p (only the region with the three GAPDH isoenzymes is shown, $n \geq 4$ ) in stationary-phase cells with immunodetection made by Western blot using rabbit anti-GAPDH as described in materials and methods; signal intensity quantification of GAPDH levels normalized to Zwf1p, which was used as internal control, and expressed as the mean \pm standard deviation in arbitrary units (a.u.) relative to control is also shown. ${ }^{*} \mathrm{P}<0.05$ vs control. 
higher $\mathrm{H}_{2} \mathrm{O}_{2}$ concentrations. In spite of this result, overall GAPDH activity and total GAPDH mRNA steadystate levels in stationary-phase cells are not altered by $\mathrm{H}_{2} \mathrm{O}_{2}$ (results not shown). A possible explanation for this discrepancy is that, in spite of the decrease in the total amount of Tdh3p plus Tdh2p, the relative proportion of Tdh $2 p$ versus Tdh $3 p$ is increased. It is known that the three isoenzymes have different kinetic constants since it has been determined that Tdh3p has a two- to three-fold lower apparent $V_{\max }$ than Tdh2p [11]. Also, it can be hypothesized that Tdh1p upregulation observed at low $\mathrm{H}_{2} \mathrm{O}_{2}$ concentrations is compensating for the decreased levels of $\mathrm{Tdh} 2 \mathrm{p} / \mathrm{Tdh} 3 \mathrm{p}$, the overall net result being that GAPDH activity is maintained constant.

Tdh1p levels have also been previously found to be induced by reductive stress caused by an excess of cytoplasmic $\mathrm{NADH}$ in an anaerobically grown gpd $2 \Delta$ strain lacking one of the glycerol-3-phosphate dehydrogenases [43]. This upregulation of Tdh1p expression by changes in cellular redox state may be related to its function in signaling pathways, possibly the Hog1p pathway. In fact, in Schizosaccharomyces pombe, a recent study [44] showed that in response to $\mathrm{H}_{2} \mathrm{O}_{2}$ stress, the Cys-152 of Tdh1p is transiently oxidized. This oxidation enhances the association of Tdh $1 \mathrm{p}$ with Mcs4p (mitotic catastrophe suppressor) and Mpr1p, a protein that transfers a phosphoryl group from the Mak2/Mak3 sensor histidine kinases activated by $\mathrm{H}_{2} \mathrm{O}_{2}$. The equivalent pathway in $S$. cerevisiae is the Hog1p pathway involved in the response to increased extracellular osmolarity, which is also activated by oxidative stress $[45,46]$.

In the last years the paradigm found in the literature is that GAPDH is a sensitive protein target of $\mathrm{H}_{2} \mathrm{O}_{2}$ and that its inhibition by $\mathrm{H}_{2} \mathrm{O}_{2}$ is a controlled response advantageous for cells because it diverts glucose from the glycolytic pathway to the pentose phosphate pathway, thus increasing the availability of NADPH for antioxidant enzymes $[12,15,47]$. In favor of such an hypothesis, a recent study [48] found that $\mathrm{H}_{2} \mathrm{O}_{2}$-induced GAPDH inactivation to about $20 \%$ of control resulted in an increase in the levels of the metabolites of the pentose phosphate pathway. Also, a mathematical model indicated that for those levels of GAPDH inhibition there was a change in the NADPH/NADP ${ }^{+}$ratio from 6.5 to 19 , with a steep increase in the ratio for levels of GAPDH inactivation greater than about $40 \%$. Ralser et al. [48] used that evidence as support of a model where GAPDH functions as a cellular switch that reroutes the carbohydrate flux to maintain the cytoplasmic NADPH/NADP ${ }^{+}$equilibrium to counteract oxidative stress. However, as shown by this work, those levels of GAPDH inactivation can only be attained under severe oxidative stress when cells are dying. Therefore, this rerouting of the glycolytic carbohydrate flux due to GAPDH inhibition, although it may be important in pathophysiological situations, is not a physiological regulatory response. Moreover, the higher GAPDH activity observed after exhaustion of carbon sources in stationaryphase cells when compared to glucose-based growth in exponential-phase cells argues against the rerouting of carbohydrate flux being an important physiological mechanism. This higher GAPDH activity in stationary-phase cells also supports the paradigm $[8,9]$ that GAPDH has other functions in the cell besides its role in glycolysis.

\section{Conclusions}

In conclusion, this work has shown that in S. cerevisiae GAPDH activity is largely unresponsive to low to moderate doses of $\mathrm{H}_{2} \mathrm{O}_{2}$. This highlights the importance of studies of $\mathrm{H}_{2} \mathrm{O}_{2}$-induced oxidative stress using concentrations closer to the physiological for determining the importance of protein oxidation phenomena in the regulation of cellular metabolism. Most other studies of GAPDH in yeast have used considerably higher concentrations of $\mathrm{H}_{2} \mathrm{O}_{2}$ than we used which lead to conclusions that are possibly only important in situations of necrosis and apoptosis. The notable exception to the lack of GAPDH response to low $\mathrm{H}_{2} \mathrm{O}_{2}$ concentrations is the $\mathrm{H}_{2} \mathrm{O}_{2}$-induced upregulation of Tdh1p expression in stationary-phase $S$. cerevisiae cells.

\section{Methods}

\section{Compounds, antibodies and other materials}

Yeast extract, bactopeptone, yea $<$ st nitrogen base and agar were from Difco, Detroit, MI, USA. Glucose oxidase (Aspergillus niger) and digitonin were from Aldrich, Steinheim, Germany. D, L-glyceraldehyde-3-phoshate, L$\alpha$-amino acid oxidase (Crotalus atrox), bovine liver catalase and phenylmethylsulfonyl fluoride were from Sigma Chemical Company, St. Louis, MO, USA. Hydrogen peroxide was obtained from Merck \& Co., Inc., Whitehouse Station, NJ, USA. Anti-glyceraldehyde-3-phoshate dehydrogenase monoclonal antibody was from Chemicon International Inc., Temecula, CA, USA and rabbit antiglyceraldehyde-3-phoshate dehydrogenase antibody was a kind gift from Dr. Pedro Moradas-Ferreira, Instituto de Biologia Molecular e Celular, Porto, Portugal. Antimouse IgG-horseradish peroxidase conjugate antibody (sc-2005) and anti-rabbit IgG-horseradish peroxidase conjugate antibody (sc-2004) were obtained from Santa Cruz Biotechnology, Inc., Santa Cruz, CA, USA).

\section{Yeast strains, media and growth conditions}

The $S$. cerevisiae strains used in this work, BY4741

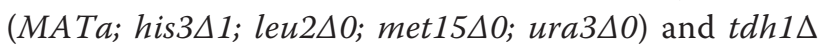
(isogenic to BY4741 with YJL052w::kanMX4), were obtained from EUROSCARF, Frankfurt, Germany. 
For all experiments $S$. cerevisiae cells were inoculated at an $\mathrm{OD}_{600}$ of 0.05 and cultured in synthetic complete (SC) medium containing $6.8 \%(\mathrm{w} / \mathrm{v})$ yeast nitrogen base, $2 \%(\mathrm{w} / \mathrm{v})$ glucose, and amino acids as indicated in [49], at $30^{\circ} \mathrm{C}$ and with shaking at $160 \mathrm{rpm}$. Exponential-phase cells were harvested at $0.5 \mathrm{OD}_{600}\left(\sim 2 \times 10^{7}\right.$ cells $)$ and stationary-phase cells were harvested after 7 days.

\section{Exposure to $\mathrm{H}_{2} \mathrm{O}_{2}$ and cell survival}

Exponential-phase cells were exposed to steady-state $\mathrm{H}_{2} \mathrm{O}_{2}$ concentrations during $60 \mathrm{~min}$ in fresh $\mathrm{SC}$ medium at $30^{\circ} \mathrm{C}$ with shaking at $160 \mathrm{rpm}$ using glucose oxidase [30]. For stationary-phase cells, cells were resuspended in an amino acid solution (0.1 M phosphate buffer, $\mathrm{pH}$ 7.4, containing amino acids with the same concentrations as in SC medium) and L- $\alpha$-amino acid oxidase was used for $\mathrm{H}_{2} \mathrm{O}_{2}$ generation [27]. Briefly, an aliquot containing the desired $\mathrm{H}_{2} \mathrm{O}_{2}$ concentration was added to the cells together with either glucose oxidase or L- $\alpha$ amino acid oxidase at such an activity that the rapid consumption of the added initial $\mathrm{H}_{2} \mathrm{O}_{2}$ concentration by the cells was compensated, thus keeping $\mathrm{H}_{2} \mathrm{O}_{2}$ concentration constant (steady-state) during the assay. Cell survival after exposure to steady-state concentrations of $\mathrm{H}_{2} \mathrm{O}_{2}$ was monitored by plating diluted sample aliquots on YPD plates [50] and counting colonies after $48 \mathrm{~h}$.

\section{Protein extracts}

Crude protein extracts were prepared by glass bead lysis. Cells were suspended either in $100 \mathrm{mM}$ potassium phosphate buffer $\mathrm{pH} 7.4$ containing $1 \mathrm{mM}$ PMSF or, in the case of two-dimensional gel electrophoresis analysis, in Tris $\mathrm{HCl} 10 \mathrm{mM}$ buffer $\mathrm{pH} 8.0$ containing $2 \mu \mathrm{M}$ DTT, protease inhibitors: $1 \mathrm{mM}$ PMSF, $1.5 \mu \mathrm{g} / \mathrm{ml}$ benzamidine, $10 \mu \mathrm{g} / \mathrm{ml}$ leupeptin, and $1 \mu \mathrm{g} / \mathrm{ml}$ pepstatin, added to an equal volume of glass beads, and vortexed for 7 cycles of $1 \mathrm{~min}$ of vortexing followed by $1 \mathrm{~min}$ of cooling on ice. The mixture was then centrifuged at $8000 \times g, 20 \mathrm{~min}$ at $8^{\circ} \mathrm{C}$. The supernatants were used for determinations of enzyme activities, total protein [51] and GAPDH levels by Western blot after SDSPAGE or two-dimensional gel electrophoresis.

\section{Enzyme activities}

Glyceraldehyde-3-phosphate dehydrogenase activity in protein extracts was assayed according to [52], with some minor modifications. NADH formation was measured at $340 \mathrm{~nm}\left(\varepsilon=6220 \mathrm{M}^{-1} \mathrm{~cm}^{-1}\right)$ during $4 \mathrm{~min}$ at $25^{\circ} \mathrm{C}$ in $1 \mathrm{ml}$ reaction medium with $0.015 \mathrm{M}$ sodium pyrophosphate buffer $\mathrm{pH} 8.5$ containing $0.03 \mathrm{M}$ sodium arsenate, $0.26 \mathrm{mM} \mathrm{NAD}^{+}, 3.5 \mathrm{mM}$ dithiothreitol (DTT) and protein extract. The reaction was started by the addition of $0.525 \mathrm{mM}$ DL-glyceraldehyde-3-phosphate. The activity assay was also performed in the absence of DTT. One unit is defined as the quantity of enzyme reducing $1 \mu \mathrm{mol} \mathrm{NAD}^{+} / \mathrm{min}$ at $25^{\circ} \mathrm{C}$ and $\mathrm{pH} 8.5$.

In exponential-phase cells catalase activity was determined in situ. Cell membrane permeabilization was achieved by incubating cells with $0.02 \%$ (w/v) digitonin, dissolved in dimethylsulphoxide, in $0.1 \mathrm{M}$ potassium phosphate buffer, $\mathrm{pH} 6.5$, for $15 \mathrm{~min}$ at $30^{\circ} \mathrm{C}$ with shaking. $\mathrm{H}_{2} \mathrm{O}_{2}$ consumption (100 $\mu \mathrm{M}$ initial concentration) by permeabilized cells suspended in the permeabilization buffer at $30^{\circ} \mathrm{C}$ was followed using an oxygen electrode (Hansatech Instruments Ltd, Norfolk, England). In stationary-phase cells catalase activity was measured spectrophotometrically in protein extracts by following $\mathrm{H}_{2} \mathrm{O}_{2}$ consumption (initial concentration, $10 \mathrm{mM}$ ) at $240 \mathrm{~nm}$ at $25^{\circ} \mathrm{C}$ for 2 min according to Aebi [53]. $\mathrm{H}_{2} \mathrm{O}_{2}$ concentrations were plotted on a semi-logarithmic graph against time and the first order rate constant (catalase activity) was calculated.

\section{SDS-PAGE and two-dimensional gel electrophoresis}

SDS-PAGE was carried out according to [54]. $50 \mu \mathrm{g}$ of total proteins were denaturated and analyzed in $7.5 \%$ $(\mathrm{w} / \mathrm{v})$ polyacrylamide $(\mathrm{w} / \mathrm{v})$. For two-dimensional analysis overnight precipitation using acetone $(1 \mathrm{ml})$ was done to protein extracts $(150 \mu \mathrm{g}$ total protein). The pellet was resuspended in $250 \mu \mathrm{l}$ of rehydration solution [8 M urea, 0.5\% (w/v) CHAPS, 0.2\% (w/v) DTT, 0.5\% (v/v) IPG buffer pH 3-10, 0.002\% (w/v) bromophenol blue], were loaded into the strip holders (Amersham Biosciences) and IEF (first dimension) was carried out on linear IPGs (pH 3-10; 13 cm long IPG) and achieved using the Ettan IPGphor system (GE Healthcare). Strips were rehydrated with $150 \mu \mathrm{g}$ of proteins extracts for 12 $\mathrm{h}$ at room temperature. Strips were then focused according to the following electrical conditions at $20^{\circ} \mathrm{C}$ : $150 \mathrm{~V}$ for $1 \mathrm{~h}, 300 \mathrm{~V}$ for $1 \mathrm{~h}, 600 \mathrm{~V}$ for $1 \mathrm{~h}$, from 600 to $4000 \mathrm{~V}$ in $90 \mathrm{~min}$ and $4000 \mathrm{~V}$ for $4 \mathrm{~h}$. After focusing IPG strips were placed for $15 \mathrm{~min}$ in equilibration buffer [6 M urea, 30\% (v/v) glycerol, 2\% (w/v) SDS, $0.05 \mathrm{M}$ Tris- $\mathrm{HCl}, \mathrm{pH} 8.8,0.002 \%(\mathrm{w} / \mathrm{v})$ bromophenol blue] containing $1 \%(\mathrm{w} / \mathrm{v})$ DTT and, subsequently, for $15 \mathrm{~min}$ in the same buffer but replacing the $1 \%(\mathrm{w} / \mathrm{v})$ DTT by $2.5 \%(\mathrm{w} / \mathrm{v})$ iodoacetamide [54]. The second dimension was carried out on $10 \%$ polyacrylamide gradient gels (16 $\times 14 \times 0.15 \mathrm{~cm})$ at $55 \mathrm{~V}$ per gel and $21^{\circ} \mathrm{C}$ until the dye front reached the bottom of the gel, according to Laemmli [54]. Identification of $\mathrm{Tdh} 1 \mathrm{p}, \mathrm{Tdh} 2 \mathrm{p}$ and Tdh3p in protein extracts from wt and $t d h 1 \Delta$ cells after SDS-PAGE or two-dimensional gel electrophoresis was made by Western blot as described below.

\section{Western blot analysis}

For immunodetection, the proteins were transferred to nitrocellulose membrane $(0.45 \mathrm{~nm}$; Schleicher and 
Schuell) in a semi-dry system, using $39 \mathrm{mM}$ glycine, 48 $\mathrm{mM}$ Tris, $0.0375 \%(\mathrm{w} / \mathrm{v})$ SDS and $20 \%(\mathrm{v} / \mathrm{v})$ methanol pH 9.2 as transfer buffer [55], during $60 \mathrm{~min}$ at $0.8 \mathrm{~mA} /$ $\mathrm{cm}^{2}$, not exceeding $25 \mathrm{~V}$. Blots were blocked at room temperature for $1 \mathrm{~h}$ in PBS $\left(4.3 \mathrm{mM} \mathrm{Na}_{2} \mathrm{HPO}_{4}, 1.4 \mathrm{mM}\right.$ $\mathrm{KH}_{2} \mathrm{PO}_{4}, 137 \mathrm{mM} \mathrm{NaCl}$ and $2.0 \mathrm{mM} \mathrm{KCl}, \mathrm{pH}$ 7.4) containing $5 \%(\mathrm{w} / \mathrm{v})$ fat-free milk powder, before incubation with the primary antibody. The mouse anti-GAPDH (Chemicon MAB374) was used with a dilution of 1:1000 whereas the rabbit anti-GAPDH was used with a dilution of 1:5000, followed by incubation for $1 \mathrm{~h}$. After washing 5 times in PBS containing 0.1\% (v/v) Tween-20, the blots were incubated for $1 \mathrm{~h}$ with the secondary antibody conjugated to horseradish peroxidase (sc-2005; 1:2000 or sc-2004; 1:5000), washed extensively with PBS and detected by enhanced chemiluminescence (ECL kit, Amersham). Protein levels were quantified by signal intensity analysis by using ImageJ [56], normalized to the protein loading, either membrane stained with Ponceau S when doing SDS-PAGE, or Zwf1p levels, and expressed as arbitrary units relative to control. For stationary-phase cells Zwf1p was used as internal control since its expression is not altered by the $\mathrm{H}_{2} \mathrm{O}_{2}$ concentrations used in this study (Cyrne et al., unpublished).

\section{Statistical analysis}

Results presented are the means \pm standard deviation of the indicated independent experiments. To determine statistical significance among groups data were analyzed using one-way analysis of variance (ANOVA) followed by post analysis with the Tukey-Kramer multiple comparisons test or, alternatively, when appropriate, Student's t-test.

\section{Authors' contributions}

LC, FA and HSM conceived the study, and participated in its design and coordination. LC performed the 2Delectrophoresis and western blot analysis. FA performed the steady-state $\mathrm{H}_{2} \mathrm{O}_{2}$ exposure of cells and helped to draft the manuscript. ASL, JDB and HSM performed the enzyme activity assays. HSM analyzed and interpreted the data and drafted the manuscript. All authors read and approved the final manuscript.

\section{List of abbreviations \\ DTT: dithiothreitol; GAPDH: Glyceraldehyde-3-phosphate dehydrogenase; S. Cerevisiae: Saccharomyces cerevisiae; SC medium: synthetic complete medium;}

\section{Acknowledgements}

This work was supported by Fundação para a Ciência e a Tecnologia (FCT), Portugal pluriannual funding. We would like to thank Prof. Pedro MoradasFerreira (Instituto de Biologia Molecular e Celular, Porto, Portugal) for the kind gift of the rabbit anti-GAPDH antibody, and Dr. Armindo Salvador (Centro de Neurociências e Biologia Celular, Universidade de Coimbra, Portugal) for helpful discussions.

\section{Author details}

${ }^{1}$ Centro de Química e Bioquímica, Faculdade de Ciências, Universidade de Lisboa, Campo Grande, 1749-016 Lisboa, Portugal. ²Departamento de Química e Bioquímica, Faculdade de Ciências, Universidade de Lisboa, Campo Grande, 1749-016 Lisboa, Portugal.

Received: 28 September 2010 Accepted: 28 December 2010 Published: 28 December 2010

\section{References}

1. Winterbourn CC, Hampton MB: Thiol chemistry and specificity in redox signaling. Free Radic Biol Med 2008, 45:549-561.

2. Janssen-Heininger YM, Mossman BT, Heintz NH, Forman HJ, Kalyanaraman B, Finkel T, Stamler JS, Rhee SG, van der Vliet A: Redox-based regulation of signal transduction: principles, pitfalls, and promises. Free Radic Biol Med 2008, 45:1-17.

3. Claiborne A, Yeh Jl, Mallett TC, Luba J, Crane EJ, Charrier V, Parsonage D: Protein-sulfenic acids: diverse roles for an unlikely player in enzyme catalysis and redox regulation. Biochemistry 1999, 38:15407-15416.

4. Saurin AT, Neubert H, Brennan JP, Eaton P: Widespread sulfenic acid formation in tissues in response to hydrogen peroxide. Proc Natl Acad Sci USA 2004, 101:17982-17987.

5. Rhee SG, Jeong W, Chang TS, Woo HA: Sulfiredoxin, the cysteine sulfinic acid reductase specific to 2-Cys peroxiredoxin: its discovery, mechanism of action, and biological significance. Kidney Int Supp/ 2007, S3-S8.

6. Cumming RC, Schubert D: Amyloid-beta induces disulfide bonding and aggregation of GAPDH in Alzheimer's disease. FASEB J 2005, 19:2060-2062.

7. Haynes CM, Titus EA, Cooper AA: Degradation of misfolded proteins prevents ER-derived oxidative stress and cell death. Mol Cell 2004, 15:767-776.

8. Sirover MA: New nuclear functions of the glycolytic protein, glyceraldehyde-3-phosphate dehydrogenase, in mammalian cells. J Cell Biochem 2005, 95:45-52.

9. Nakajima H, Amano W, Kubo T, Fukuhara A, Ihara H, Azuma YT, Tajima H, Inui T, Sawa A, Takeuchi T: Glyceraldehyde-3-phosphate dehydrogenase aggregate formation participates in oxidative stress-induced cell death. $J$ Biol Chem 2009, 284:34331-34341.

10. McAlister L, Holland MJ: Isolation and characterization of yeast strains carrying mutations in the glyceraldehyde-3-phosphate dehydrogenase genes. J Biol Chem 1985, 260:15013-15018.

11. McAlister L, Holland MJ: Differential expression of the three yeast glyceraldehyde-3-phosphate dehydrogenase genes. J Biol Chem 1985, 260:15019-15027.

12. Ravichandran V, Seres T, Moriguchi T, Thomas JA, Johnston RB Jr: Sthiolation of glyceraldehyde-3-phosphate dehydrogenase induced by the phagocytosis-associated respiratory burst in blood monocytes. J Biol Chem 1994, 269:25010-25015.

13. Schuppe-Koistinen I, Moldeus P, Bergman T, Cotgreave IA: S-thiolation of human endothelial cell glyceraldehyde-3-phosphate dehydrogenase after hydrogen peroxide treatment. Eur J Biochem 1994, 221:1033-1037.

14. Hwang NR, Yim SH, Kim YM, Jeong J, Song EJ, Lee Y, Lee JH, Choi S, Lee KJ: Oxidative modifications of glyceraldehyde-3-phosphate dehydrogenase play a key role in its multiple cellular functions. Biochem J 2009, 423:253-264.

15. Grant CM, Quinn KA, Dawes IW: Differential protein S-thiolation of glyceraldehyde-3-phosphate dehydrogenase isoenzymes influences sensitivity to oxidative stress. Mol Cell Biol 1999, 19:2650-2656.

16. Shenton D, Grant CM: Protein S-thiolation targets glycolysis and protein synthesis in response to oxidative stress in the yeast Saccharomyces cerevisiae. Biochem J 2003, 374:513-519.

17. Cabiscol E, Piulats E, Echave P, Herrero E, Ros J: Oxidative stress promotes specific protein damage in Saccharomyces cerevisiae. J Biol Chem 2000, 275:27393-27398.

18. Costa VM, Amorim MA, Quintanilha A, Moradas-Ferreira P: Hydrogen peroxide-induced carbonylation of key metabolic enzymes in Saccharomyces cerevisiae: the involvement of the oxidative stress response regulators Yap1 and Skn7. Free Radic Biol Med 2002, 33:1507-1515. 
19. Yoo BS, Regnier FE: Proteomic analysis of carbonylated proteins in twodimensional gel electrophoresis using avidin-fluorescein affinity staining. Electrophoresis 2004, 25:1334-1341.

20. Shenton D, Perrone G, Quinn KA, Dawes IW, Grant CM: Regulation of protein S-thiolation by glutaredoxin 5 in the yeast Saccharomyces cerevisiae. J Biol Chem 2002, 277:16853-16859.

21. Oliveira-Marques V, Marinho HS, Cyrne L, Antunes F: Role of hydrogen peroxide in NF-kappaB activation: from inducer to modulator. Antioxid Redox Signal 2009, 11:2223-2243.

22. Izawa S, Inoue $Y$, Kimura A: Importance of catalase in the adaptive response to hydrogen peroxide: analysis of acatalasaemic Saccharomyces cerevisiae. Biochem J 1996, 320:61-67.

23. Lee J, Godon C, Lagniel G, Spector D, Garin J, Labarre J, Toledano MB: Yap1 and Skn7 control two specialized oxidative stress response regulons in yeast. J Biol Chem 1999, 274:16040-16046.

24. Martinez-Pastor MT, Marchler G, Schuller C, Marchler-Bauer A, Ruis H, Estruch F: The Saccharomyces cerevisiae zinc finger proteins Msn2p and Msn4p are required for transcriptional induction through the stress response element (STRE). EMBO J 1996, 15:2227-2235.

25. Delaunay $A$, Isnard AD, Toledano MB: $\mathrm{H} 2 \mathrm{O} 2$ sensing through oxidation of the Yap1 transcription factor. EMBO J 2000, 19:5157-5166.

26. Boisnard S, Lagniel G, Garmendia-Torres C, Molin M, Boy-Marcotte E, Jacquet M, Toledano MB, Labarre J, Chedin S: $\mathrm{H} 2 \mathrm{O} 2$ activates the nuclear localization of Msn2 and Maf1 through thioredoxins in Saccharomyces cerevisiae. Eukaryot Cell 2009, 8:1429-1438.

27. Sousa-Lopes A, Antunes F, Cyrne L, Marinho HS: Decreased cellular permeability to $\mathrm{H} 2 \mathrm{O} 2$ protects Saccharomyces cerevisiae cells in stationary phase against oxidative stress. FEBS Lett 2004, 578:152-156.

28. Le Moan N, Clement G, Le Maout S, Tacnet F, Toledano MB: The Saccharomyces cerevisiae proteome of oxidized protein thiols: contrasted functions for the thioredoxin and glutathione pathways. $J$ Biol Chem 2006, 281:10420-10430.

29. McDonagh B, Ogueta S, Lasarte G, Padilla CA, Barcena JA: Shotgun redox proteomics identifies specifically modified cysteines in key metabolic enzymes under oxidative stress in Saccharomyces cerevisiae. $J$ Proteomics 2009, 72:677-689.

30. Branco MR, Marinho HS, Cyrne L, Antunes F: Decrease of H2O2 plasma membrane permeability during adaptation to $\mathrm{H} 2 \mathrm{O} 2$ in Saccharomyces cerevisiae. J Biol Chem 2004, 279:6501-6506

31. Norbeck J, Blomberg A: Two-dimensional electrophoretic separation of yeast proteins using a non-linear wide range $(\mathrm{pH} 3-10)$ immobilized $\mathrm{pH}$ gradient in the first dimension; reproducibility and evidence for isoelectric focusing of alkaline ( $\mathrm{pl}>$ 7) proteins. Yeast 1997, 13:1519-1534.

32. Boucherie H, Bataille N, Fitch IT, Perrot M, Tuite MF: Differential synthesis of glyceraldehyde-3-phosphate dehydrogenase polypeptides in stressed yeast cells. FEMS Microbiol Lett 1995, 125:127-133.

33. Delgado ML, O'Connor JE, Azorin I, Renau-Piqueras J, Gil ML, Gozalbo D: The glyceraldehyde-3-phosphate dehydrogenase polypeptides encoded by the Saccharomyces cerevisiae TDH1, TDH2 and TDH3 genes are also cell wall proteins. Microbiology 2001, 147:411-417.

34. Godon C, Lagniel G, Lee J, Buhler J-M, Kieffer S, Perrot M, Boucherie H, Toledano MB, Labarre J: The $\mathrm{H}_{2} \mathrm{O}_{2}$ stimulon in Saccharomyces cerevisiae. J Biol Chem 1998, 273:22480-22489.

35. Gasch AP, Spellman PT, Kao CM, Carmel-Harel O, Eisen MB, Storz G, Botstein D, Brown PO: Genomic expression programs in the response of yeast cells to environmental changes. Mol Biol Cell 2000, 11:4241-4257.

36. Halliwell B, Clement MV, Long LH: Hydrogen peroxide in the human body. FEBS Lett 2000, 486:10-13.

37. Baty JW, Hampton MB, Winterbourn CC: Proteomic detection of hydrogen peroxide-sensitive thiol proteins in Jurkat cells. Biochem J 2005, 389:785-795.

38. Cumming RC, Andon NL, Haynes PA, Park M, Fischer WH, Schubert D: Protein disulfide bond formation in the cytoplasm during oxidative stress. J Biol Chem 2004, 279:21749-21758.

39. Antunes F, Cadenas E: Cellular titration of apoptosis with steady-state concentrations of $\mathrm{H}_{2} \mathrm{O}_{2}$. Sub-micromolar levels of $\mathrm{H}_{2} \mathrm{O}_{2}$ induce apoptosis through Fenton chemistry independent of cellular thiol state. Free Radic Biol Med 2001, 30:1008-1018.

40. Greetham D, Vickerstaff J, Shenton D, Perrone GG, Dawes IW, Grant CM: Thioredoxins function as deglutathionylase enzymes in the yeast Saccharomyces cerevisiae. BMC Biochem 2010, 11:3.
41. Luikenhuis S, Perrone G, Dawes IW, Grant CM: The yeast Saccharomyces cerevisiae contains two glutaredoxin genes that are required for protection against reactive oxygen species. Mol Biol Cell 1998, 9:1081-1091.

42. Garrido EO, Grant CM: Role of thioredoxins in the response of Saccharomyces cerevisiae to oxidative stress induced by hydroperoxides. Mol Microbiol 2002, 43:993-1003.

43. Valadi H, Valadi A, Ansell R, Gustafsson L, Adler L, Norbeck J, Blomberg A: $\mathrm{NADH}$-reductive stress in Saccharomyces cerevisiae induces the expression of the minor isoform of glyceraldehyde-3-phosphate dehydrogenase (TDH1). Curr Genet 2004, 45:90-95.

44. Morigasaki S, Shimada K, Ikner A, Yanagida M, Shiozaki K: Glycolytic enzyme GAPDH promotes peroxide stress signaling through multistep phosphorelay to a MAPK cascade. Mol Cell 2008, 30:108-113.

45. Singh KK: The Saccharomyces cerevisiae SIn1p-Ssk1p two-component system mediates response to oxidative stress and in an oxidant-specific fashion. Free Radic Biol Med 2000, 29:1043-1050.

46. Bilsland E, Molin C, Swaminathan S, Ramne A, Sunnerhagen P: Rck1 and Rck2 MAPKAP kinases and the HOG pathway are required for oxidative stress resistance. Mol Microbiol 2004, 53:1743-1756.

47. Grant CM: Metabolic reconfiguration is a regulated response to oxidative stress. J Biol 2008, 7:1.

48. Ralser M, Wamelink MM, Kowald A, Gerisch B, Heeren G, Struys EA, Klipp E, Jakobs $C$, Breitenbach $M$, Lehrach $H$, et al: Dynamic rerouting of the carbohydrate flux is key to counteracting oxidative stress. J Biol 2007, 6:10.

49. Folmer $\mathrm{V}$, Pedroso N, Matias AC, Lopes SCDN, Antunes F, Cyrne L, Marinho HS: $\mathrm{H} 2 \mathrm{O} 2$ induces rapid biophysical and permeability changes in the plasma membrane of Saccharomyces cerevisiae. Biochim Biophys Acta 2008, 1778:1141-1147.

50. Johnston JR: In Molecular Genetics of Yeast. A practical approach. Edited by: Johnston JR. New York: IRL Press; 1994:261-265.

51. Peterson GL: A simplification of the protein assay method of Lowry et al. which is more generally applicable. Anal Biochem 1977, 83:346-356.

52. Velick SF: Glyceraldehyde-3-Phosphate Dehydrogenase from Muscle. Methods Enzymol 1955, 1:401-406.

53. Aebi HE: Catalase. In Methods of Enzymatic Analysis. Edited by: Bergmeyer HU. Weinheim: Verlag Chemie; 1984:273-284.

54. Laemmli UK: Cleavage of structural proteins during the assembly of the head of bacteriophage T4. Nature 1970, 227:680-685.

55. Bjerrum OJ, Schafer-Nielsen C: In Analytical Electrophoresis. Edited by: Dunn MJ. Weinheim: Verlag Chemie; 1986:315

56. Rasband WS: ImageJ. U. S. National Institutes of Health, Bethesda, Maryland, USA; 1997.

doi:10.1186/1471-2091-11-49

Cite this article as: Cyrne et al:: Glyceraldehyde-3-phosphate

dehydrogenase is largely unresponsive to low regulatory levels of hydrogen peroxide in Saccharomyces cerevisiae. BMC Biochemistry 2010 11:49.

\section{Submit your next manuscript to BioMed Central and take full advantage of:}

- Convenient online submission

- Thorough peer review

- No space constraints or color figure charges

- Immediate publication on acceptance

- Inclusion in PubMed, CAS, Scopus and Google Scholar

- Research which is freely available for redistribution

Submit your manuscript at www.biomedcentral.com/submit
C Biomed Central 